\title{
PEMETAAN KEBAKARAN HUTAN DAN LAHAN KABUPATEN TANAH BUMBU KALIMANTAN SELATAN MENGGUNAKAN APLIKASI SISTEM INFORMASI GEOGRAFIS
}

\author{
Agus Sarwo Edi Sudrajat ${ }^{1}$ \\ Agnesia Putri Kurnianingtyas ${ }^{2}$ \\ Program Studi Perencanaan Wilayah dan Kota, Fakultas Teknik Universitas Semarang \\ Penulis Koresponden e-mail: agus.sarwo@yahoo.com
}

\begin{abstract}
Forest and land fires are one of the main factors in forest destruction, so as in Tanah Bumbu District, South Kalimantan Province. It always occur every year especially during the dry season. This study aims to obtain the distribution of the risk area for forest and land fires in Tanah Bumbu District and to map the areas based on their level of forest and land fires vulnerability using geographic information system. Geospacial modelling to map the vulnerability of forest and land fires uses six parameters, those are hotspot distribution, land use and land cover, topography, hydrology (river accesibility), rain fall, and demographic and settlement accesibility data. The analytical method used are overlay, skoring, and descriptive method.

The results of this study indicate that the vulnerability of forest and land fire in Tanah Bumbu district consists of five classes, those are secure zone of 166.570, 21 ha (32,87\%), not vulnerable zone of 159.477,86 ha (31,47\%), a bit vulnerable zone of 97.297,33 ha (19,2\%), vulnerable zone of 59.862,88 ha $(11,81 \%)$, and a verry vulnerable zone of $23.487,68 \mathrm{ha}(4,63 \%)$. Land cover with high risk of forest and land fire are shrubs, dry land agriculture, secondary forest, plantations, and plantation forests. While Kecamatan Satui and Kecamatan Kusan Hulu area the area that very vurnerable.
\end{abstract}

Keywords: forest and land fires, vurnerability, geospatial modelling, geographic information system

\begin{abstract}
ABSTRAK
Kebakaran hutan dan lahan merupakan salah satu faktor utama dalam kerusakan hutan, begitu pula di Kabupaten Tanah Bumbu Provinsi Kalimantan Selatan. Setiap tahun kebakaran hutan dan lahan selalu terjadi, terutama pada musim kemarau. Penelitian ini bertujuan untuk memperoleh sebaran daerah resiko kebakaran hutan dan lahan di Kabupaten Tanah Bumbu serta memetakan daerah rawan kebakaran hutan dan lahan berdasarkan tingkatan kerawanannya menggunakan sistem informasi geografis. Pemodelan geospasial untuk membuat peta kerawanan menggunakan enam parameter yaitu sebaran hotspot, penggunaan lahan dan tutupan lahan, topografi, hidrologi khususnya aksesibilitas terhadap sungai, curah hujan, serta data demografi dan aksesibilitas permukiman. Metode analisis yang digunakan adalah metode tumpang susun (overlay), pembobotan, dan deskriptif.

Hasil penelitian ini menunjukkan bahwa kerawanan kebakaran hutan di kabupaten Tanah Bumbu terdiri dari lima kelas yaitu daerah aman seluas 166.570, 21 hektar (32,87\%), daerah tidak rawan seluas 159.477,86 hektar (31,47\%), daerah agak rawan seluas 97.297,33 hektar (19,2\%), daerah rawan seluas $59.862,88$ hektar $(11,81 \%)$, dan daerah sangat rawan seluas 23.487,68 hektar (4,63\%). Tutupan lahan yang paling sering terjadi kebakaran hutan dan lahan adalah belukar, pertanian lahan kering, hutan sekunder, perkebunan, dan hutan tanaman. Daerah paling rawan terhadap kebakaran hutan dan lahan adalah Kecamatan Satui dan Kecamatan Kusan Hulu.
\end{abstract}

Kata Kunci: kebakaran hutan dan lahan, kerawanan, pemodelan geospasial, sistem informasi geografis 
Jurnal Planologi Vol. 17 No. 2, Oktober 2020

Available : http://jurnal.unissula.ac.id/index.php/psa

\section{PENDAHULUAN}

Hutan merupakan suatu ekosistem yang berisi sumber daya alam yang tidak ternilai harganya. Tidak hanya berfungsi sebagai habitat keanekaragaman hayati, hutan juga berfungsi untuk memberikan hasil hutan baik kayu maupun non kayu, sebagai daerah resapan air dan pencegah banjir, hingga berfungsi untuk kepentingan ilmu pengetahuan dan pariwisata. Fungsi lain yang tak kalah penting dari hutan adalah sebagai penyerap karbon diosida untuk mengurangi pemanasan global serta sebagai penghasil oksigen yang membantu kelangsungan kehidupan makhluk hidup di bumi. Hutan juga merupakan sumberdaya alam yang tidak ternilai karena didalamnya terkandung keanekaragaman hayati sebagai sumber plasma nutfah, sumber hasil hutan kayu dan non-kayu, pengatur tata air, pencegah banjir dan erosi serta kesuburan tanah, perlindungan alam hayati untuk kepentingan ilmu pengetahuan, kebudayaan, rekreasi, pariwisata dan sebagainya (Pualilin Yuliandri dkk. 2019). Gambut yang mengalami kekeringan karena proses alamiah maupun karena adanya drainase menyebabkan bahan-bahan organik kadar airnya rendah (kering) sehingga lebih mudah terbakar jika ada pemicunya (Samsuri dkk. 2012).

Namun dibalik potensinya yang besar, hutan di Indonesia memiliki ancaman kerusakan hutan yang cukup besar. Salah satu ancaman tersebut adalah kebakaran hutan dan lahan yang semakin marak terjadi. Kebakaran hutan yang terjadi di Indonesia disebabkan karena beberapa faktor, diantaranya pembakaran liar untuk perubahan lahan dan perubahan iklim global yang menyebabkan kemarau panjang. Perubahan iklim global berupa peningkatan suhu mengakibatkan fenomena El-Nino di kawasan Asia Tenggara lebih sering terjadi yang mengakibatkan kemarau panjang dan lahan menjadi kering sehingga mudah terbakar (Nursoleha, 2014; Amri dalam Kusumajaya, 2019).

Disamping itu, Tingkat kekeringan lahan akan sangat berpengaruh pada kerawanan untuk terjadinya kebakaran. Tingkat kekeringan lahan pada umumnya dipengaruhi oleh kadar air yang ada di dalam tanah dan dan kandungan air di dalam biomassa tanaman. Keduanya erat kaitannya dengan kemampuan tanah menyediakan air yang diperlukan tanaman, musim kemarau dan jenis tanamannya. Semakin mudah tanaman terbakar, semakin panjang musim kemarau, dan semakin kering kondisi lahannya, semakin mudah terjadinya kebakaran. Di lahan gambut, kebakaran lahan erat kaitannya dengan kandungan bahan organik yang tinggi dan berpeluang memudahkan terjadinya kebakaran lahan di musim kemarau (Moehansyah,2015) 
Jurnal Planologi Vol. 17 No. 2, Oktober 2020

Available : http://jurnal.unissula.ac.id/index.php/psa

Kebakaran hutan dan lahan yang terjadi sangat berpengaruh terhadap berbagai sektor, baik dari gangguan kesehatan, hambatan transoportasi, kerusakan ekologis, dan penurunan ekonomi. World Wildlife Fund (WWF) menyatakan bahwa di tahun 1997, kerugian yang diakibatkan oleh kebakaran hutan dan lahan mencapai hingga 4,4 milyar dolar Amerika Serikat dan World Health Organization (WHO) menyatakan sekitar 20 juta orang Indonesia terkena dampak asap kebakaran hutan berupa gangguan paru dan pernapasan (Farandika dan Hartono, 2016).

Kabupaten Tanah Bumbu yang berada di Kalimantan Selatan juga tidak luput dari permasalahan kebakaran hutan dan lahan ini. Dari luas wilayah sebesar 506.696 ha, sekitar $63 \%$ wilayahnya masih merupakan hutan, $19,5 \%$ untuk pertanian, ladang dan perkebunan sedangkan sisanya untuk permukiman. Kondisi ini menyebabkan ancaman kebakaran hutan cukup tinggi. Pada tahun 2019, BPBD Kalimantan Selatan menetapkan Kabupaten Tanah Bumbu menjadi siaga Karhutla (kebakaran hutan dan lahan) karena di bulan Oktober kebakaran hutan dan lahan mencapai 700 hektar (www.regional.kompas.com).

Berdasarkan Undang-Undang Nomor 24 Tahun 2007 tentang Penanggulangan Bencana, Pemerintah Daerah memiliki wewenang untuk menetapkan kebijakan penanggulanagn bencana dan memasukkan kebijakan tersebut dalam perencanaan pembangunan. Adapun Badan Penanggulangan Bencana Daerah memiliki beberapa tugas, salah satunya untuk menyusun, menetapkan dan menginformasikan peta rawan bencana yang dapat dimanfaatkan sebagai upaya untuk penanggulangan kebakaran hutan dan lahan. Penyajian informasi kerawanan bencana kebakaran hutan secara spasial dapat membantu merepresentasikan kondisi di lapangan terkait lokasi, jarak serta aksesibilitas lokasi daerah rawan kebakaran dengan sumber daya pemadam kebakaran yang ada (Solichin dalam Kusmajaya, 2019). Terdapat 7 parameter yang digunakan dalam pemetaan kerawanan kebakaran hutan dan lahan ini yakni aksesibilitas terhadap jalan, aksesibilitas terhadap sungai, suhu permukaan, curah hujan, kepadatan hotspot, perizinan lahan dan penutup/penggunaan lahan (Farandika dan Hartono, 2016). Sedangkan menurut Putri Amalina (2015), Variabel kebakaran hutan dibagi menjadi faktor alam dan faktor manusia. Faktor alam terdiri dari tutupan lahan, indeks vegetasi, indeks kelembaban, dan suhu permukaan. Faktor manusia terdiri dari jarak dari aksesibilitas dan pusat aktivitas masyarakat. 
Semua kerentanan bencana akan memberikan dampak terhadap fisik kawasan, ekonomi dan sosial (Rahman, 2019). Salah satu teknologi yang dapat digunakan untuk menyusun peta kerawanan kebakaran hutan dan lahan adalah Sistem Informasi Geografis (SIG). Sistem ini dapat dilakukan dengan berbagai analisis keruangan (analisis spasial) mulai dari mengedit, memperbaharui, memanipulasi, menyimpan dan menayangkan data spasial. Integrasi antara data keruangan dan data numerik juga dapat dilakukan menggunakan sistem ini. Dalam kaitannya dengan kebakaran hutan, SIG dapat diaplikasikan untuk mendeteksi tingkat kerawanan dengan menggunakan data hotspot.

Penelitian ini bertujuan untuk memperoleh sebaran daerah resiko kebakaran hutan dan lahan di Kabupaten Tanah Bumbu serta memetakan daerah rawan kebakaran hutan dan lahan berdasarkan tingkatan kerawanannya. Dengan adanya informasi spasial berupa peta kerawanan kebakaran hutan di Kabupaten Tanah Bumbu, diharapkan dapat meningkatkan kinerja pemerintah daerah dalam upaya penanggulangan bencana kebakaran hutan mulai dari tahap pencegahan, tanggap darurat, hingga pemulihan pasca kebakaran hutan. Pemerintah Daerah juga dapat menggunakan peta ini sebagai dasar untuk penentuan daerah yang diprioritaskan untuk segera ditangani serta untuk perencanaan penggunaan lahan yang komprehensip dan menggabungkannya dengan pembangunan berkelanjutan.

\section{METODOLOGI}

\subsection{Waktu dan Lokasi Penelitian}

Penelitian ini dilaksanakan pada Tahun 2019 di Kabupaten Tanah Bumbu. Kabupaten Tanah Bumbu merupakan salah satu Kabupaten di Provinsi Kalimantan Selatan dengan luas sebesar 506.696 hektar. Secara geografis Kabupaten Tanah Bumbu terletak diantara $2^{\circ} 52$ - $3^{\circ} 47^{\prime}$ Lintang Selatan dan $115^{\circ} 15^{\prime}-116^{\circ} 04^{\prime}$ Bujur Timur.

\subsection{Pengumpulan Data}

Input data yang digunakan sebagai faktor pembangun model adalah data spasial faktor biofisik, aktifitas manusia, dan data hot spot (titik panas) hasil olahan dari citra NOAA AVHRR. (Samsuri dkk. 2012)

Pengumpulan data dilakukan secara primer dan sekunder. Data sekunder dijadikan sebagai sumber data untuk analisis awal mengenai resiko kebakaran sekaligus untuk menghindari duplikasi data. Selanjutnya dilakukan pengambilan data primer yang berperan juga sebagai field check hasil analisis awal tersebut. Data primer yang diperoleh langsung 
di lapangan ditujukan untuk mendapatkan informasi langsung mengenai sejarah dan kemungkinan terjadinya kebakaran hutan dan lahan.

Data-data sekunder yang diperlukan dalam analisis kerawanan kekeringan adalah:

a) Data titik api (hotspot) selama 10 tahun terakhir (2007 - 2017)

b) Data Topografi : Model Elevasi Digital, garis kontur Peta Rupabumi Indonesia dan ASTER GDEM. Ketiga sumber data topografi tersebut dianalisis baik secara quantitatif menggunakan hydrologic modelling maupun analisis visual.

c) Penggunaan Lahan dan Penutupan Lahan : Hasil interpretasi citra satelit Landsat dan ALOS, peta RTRWK, Konsesi (HGU, HTI, HPH, KP, dll), dan data land cover Peta Rupabumi Indonesia.

d) Data hidrologi: Jejaring sungai/handil/parit/ irigasi, debit sungai. Informasi hidrologi adalah sebagai pelengkap dan alat kontrol hasil analisis.

e) Iklim dan cuaca khususnya data curah hujan (isohyet)

f) Demografi: Sebaran penduduk, sebaran bangunan dan obyek penting Adapun alat yang digunakan dalam penelitian ini meliputi perangkat keras (hardware) yaitu seperangkat personal computer (PC), aplikasi program ArcGis, kamera digital, dan alat untuk tulis menulis.

\subsection{Pengolahan dan Analisis Data}

Metode analisis data dalam penelitian ini meliputi metode analisis tumpang susun (overlay), metode pengharkatan, dan metode deskriptif. Adapun proses pengolahan dan analiais data dalam penelitian ini melputi:

1. Penyamaan data spasial

Pada tahap awal, semua data spasial yang telah diperoleh disamakan datum dan proyeksinya menjadi datum WGS 1984 dab proyeksi UTM Zona $50 \mathrm{~S}$.

\section{Pembobotan Resiko Kebakaran Hutan}

Analisis resiko kebakaran hutan dilakukan dengan menggunakan data sebaran titik panas (hotspot). Data hotspot diambil dari arsip NASA dengan kurun waktu 10 tahun (2007-2017) dan memiliki resolusi spasial $1 \mathrm{~km}$ x $1 \mathrm{~km}$. Titik panas yang diambil adalah titik panas yang mempunyai tingkat kepercayaan lebih besar atau sama dengan $70 \%$ dari indikasi yang ditangkap oleh instrument MODIS pada satelit Terra dan Aqua.

Data tersebut dianalisis dengan menggunakan analisis kerapatan (density analysis) untuk menghasilkan frekuensi dan sebaran areal kebakaran hutan dan lahan di Kabupaten Tanah Bumbu. Analisis ini dilakukan juga dengan menggunakan metode pembobotan 
untuk membagi kelas resiko bencana kebakaran yang ada seperti yang terjadi pada Tabel 1 . Hasil Analisis dengan analisis spasial masih dievaluasi secara visual dengan membandingkan areal kebakaran dengan penampakan visual citra Landsat dan quick bird serta jejaring saluran (sungai) hasil analisis hidrologi. Data resiko kebakaran hutan dan lahan adalah berupa data spasial daerah-daerah yang memiliki kemungkinan terjadi kebakaran dalam suatu periode pengulangan tertentu. Semakin sering kemungkinan terjadinya kebakaran semakin tinggi resiko kebakaran hutan dan lahan.

Tabel 1. Skoring Resiko Kebakaran Hutan dan Lahan

\begin{tabular}{|c|c|c|c|}
\hline Skor & $\begin{array}{c}\text { Frekuensi Kebakaran } \\
\text { Hutan dan Lahan }\end{array}$ & Keterangan & Kategori \\
\hline 1 & - & $\begin{array}{c}\text { Tidak Pernah terjadi } \\
\text { kebakaran }\end{array}$ & Aman \\
\hline 2 & $>5$ th & Setiap $>5$ th & Tidak Bahaya \\
\hline 3 & 5 th & Setiap $<5$ th & Agak Bahaya \\
\hline 4 & 3 th & Setiap $<3$ th & Bahaya \\
\hline 5 & 1 th & Setiap 1 th & Sangat Bahaya \\
\hline
\end{tabular}

\section{Tumpang Susun (Overlay) Kerawanan Kebakaran Hutan dan Lahan}

Tumpang susun (overlay) dilakukan antara peta resiko kebakaran dengan penggunaan lahan/ tutupan lahan, aksesibilitas (jaringan jalan, sungai), permukiman dan bangunanbangunan penting, iklim dan topografi serta sejarah kejadian kebakaran hutan dan lahan. Setelah dilakukan overlay, kemudian dilakukan analisis deskriptif untuk mengetahui keterkaitan antara sebaran resiko kebakaran dengan penggunaan lahannya. Selanjutnya dilakukan pemetaan akhir untuk menghasilkan peta zonasi kerawanan kebakaran berdasarkan resiko kebakaran dengan penggunaan lahan. Hasil overlay dapat memberikan gambaran situasi baru hasil dari berbagai macam peta kondisi (Sakarov, 2019).

Interpretasi citra penggunaan lahan yang digunakan adalah interpretasi citra Landsat tahun 2016. Kodefikasi interpretasi menggunakan kodefikasi kelas penutupan lahan dalam penafsiran citra satelit optis resolusi sedang di bidang kehutanan, yang sudah masuk dalam nomenklatur SNI (Standar Nasional Indonesia). 
Jurnal Planologi Vol. 17 No. 2, Oktober 2020

Available: http://jurnal.unissula.ac.id/index.php/psa

\section{HASIL DAN PEMBAHASAN}

\subsection{Penggunaan Lahan / Tutupan Lahan}

Secara umum wilayah kabupaten Tanah Bumbu tutupan lahanya didominasi oleh Hutan sekunder (Hs) seluas 156.634 ha diikuti kemudian oleh tutupan Perkebunan (Pk) seluas 83.360 ha, tutupan Pertanian lahan kering (Pt) seluas 79.406 ha, tutupan Belukar (B) seluas 75.202 ha dan Pertambangan $(\mathrm{Pb})$ seluas 18.296 ha. Hutan sekunder terluas ada di kecamatan Kusan Hulu. Perkebunan terluas ada di kecamatan Satui. Pertanian lahan kering terluas ada di kecamatan Mantewe. Belukar terluas ada di kecamatan Satui dan area pertambangan terluas ada di kecamatan Satui pula.

Tabel 2. Tutupan Lahan di Kabupaten Tanah Bumbu

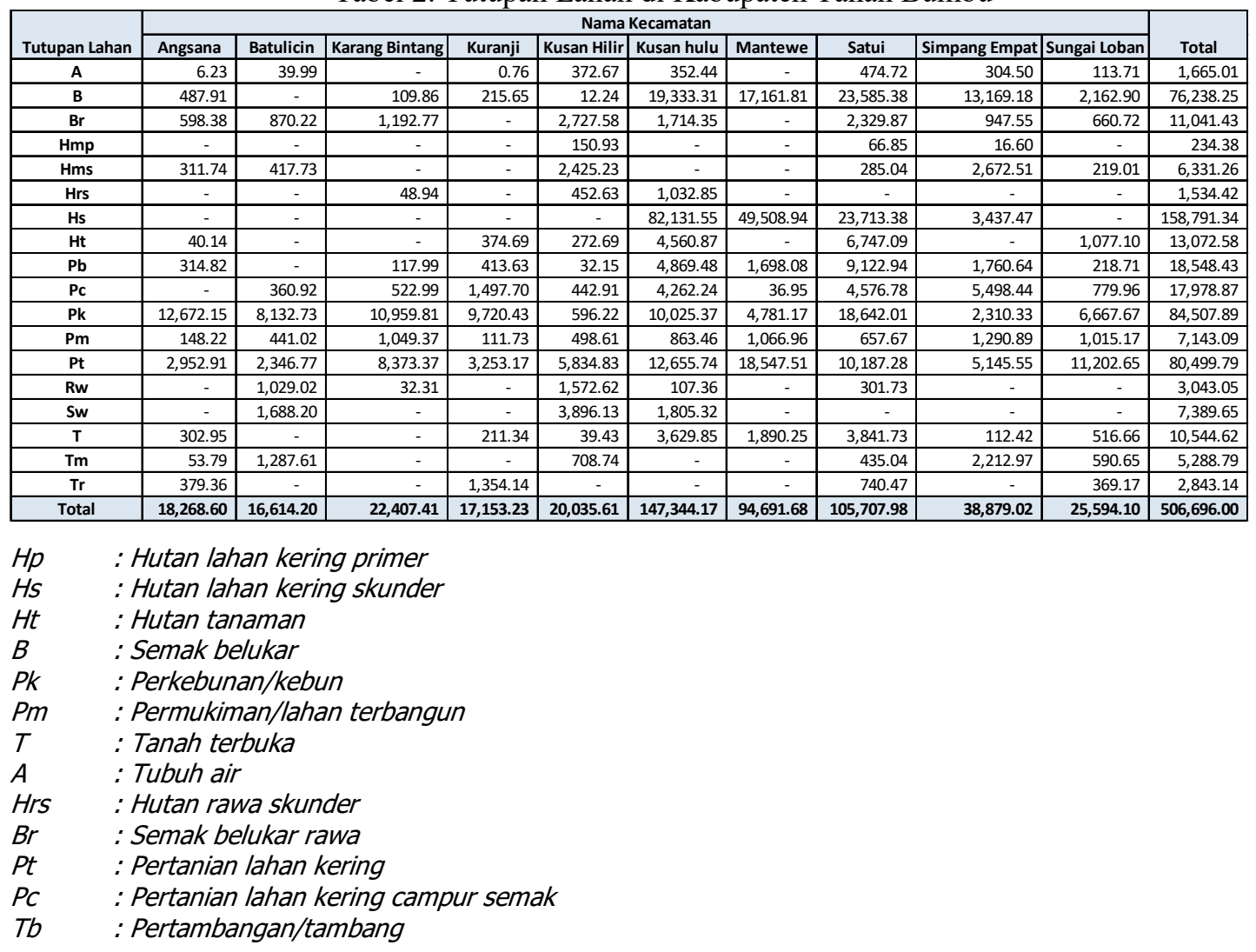


Jurnal Planologi Vol. 17 No. 2, Oktober 2020

Available : http://jurnal.unissula.ac.id/index.php/psa

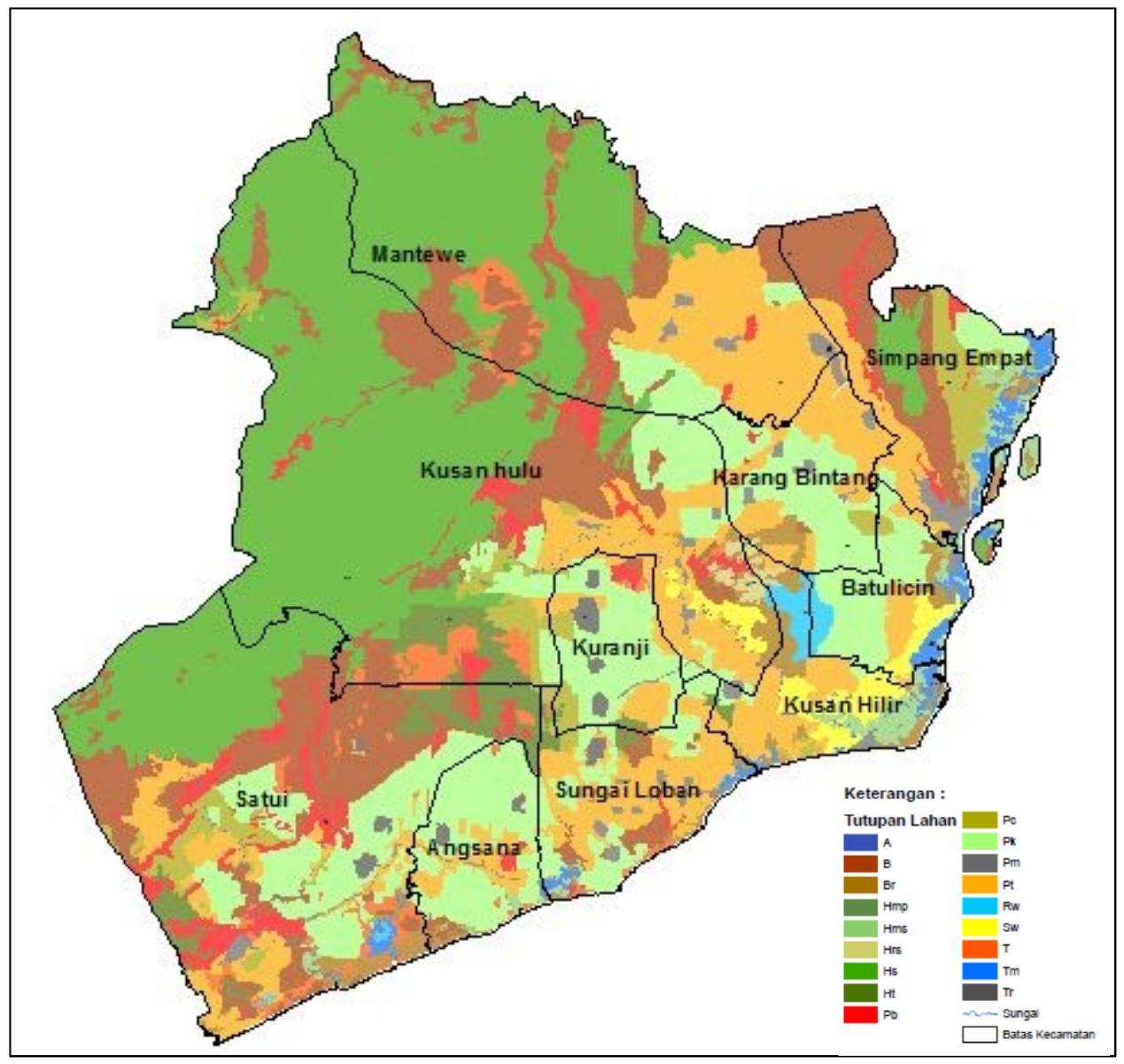

Gambar 1. Tutupan Lahan Kabupaten Tanah Bumbu

\subsection{Sebaran Titik Panas (Hotspot)}

Selama 10 tahun (2007-2017) titik panas terbanyak terjadi pada tahun 2015 sebanyak 445 kali dan pada tahun 2014 sebanyak 181 kali diseluruh wilayah kabupaten Tanah Bumbu. Sementara kecamatan yang terbanyak titik apinya selama 10 tahun terakhir adalah kecamatan Satui sebanyak 263 titik panas dan diikuti oleh kecamatan Kusan Hulu sebanyak 236 titik panas.

Tabel 3. Titik Panas (Hotspot) di Kabupaten Tanah Bumbu (2007-2017)

\begin{tabular}{|c|c|c|c|c|c|c|c|c|c|c|c|c|}
\hline \multirow[b]{2}{*}{ Nama Kecamatan } & \multicolumn{12}{|c|}{ Tahun } \\
\hline & 2007 & 2008 & 2009 & 2010 & 2011 & 2012 & 2013 & 2014 & 2015 & 2016 & 2017 & Total \\
\hline Angsana & & & & & & \begin{tabular}{|l|}
1 \\
\end{tabular} & & 2 & 3 & & & 6 \\
\hline Batulicin & & & 6 & & 1 & 3 & 1 & 4 & 16 & & & 31 \\
\hline Karang Bintang & 3 & 2 & 10 & & 4 & 4 & & 8 & 26 & & & 57 \\
\hline Kuranji & 1 & & 1 & & 1 & 9 & 1 & 8 & 11 & & & 32 \\
\hline Kusan Hilir & & & 10 & & 8 & 8 & 1 & 18 & 17 & & & 62 \\
\hline Kusan hulu & 5 & 1 & 21 & & 13 & 10 & 3 & 57 & 124 & 2 & & 236 \\
\hline Mantewe & 4 & & 10 & & 7 & 4 & 14 & 38 & 76 & 1 & & 154 \\
\hline Satui & 5 & & 38 & 1 & 19 & 19 & 15 & 35 & 130 & & 1 & 263 \\
\hline Simpang Empat & 2 & & 13 & & 1 & 5 & 1 & 7 & 31 & 24 & & 84 \\
\hline Sungai Loban & & & 2 & & & 6 & 5 & 4 & 11 & & & 28 \\
\hline Total & 20 & 3 & 111 & 1 & 54 & 69 & 41 & 181 & 445 & 27 & 1 & 953 \\
\hline
\end{tabular}




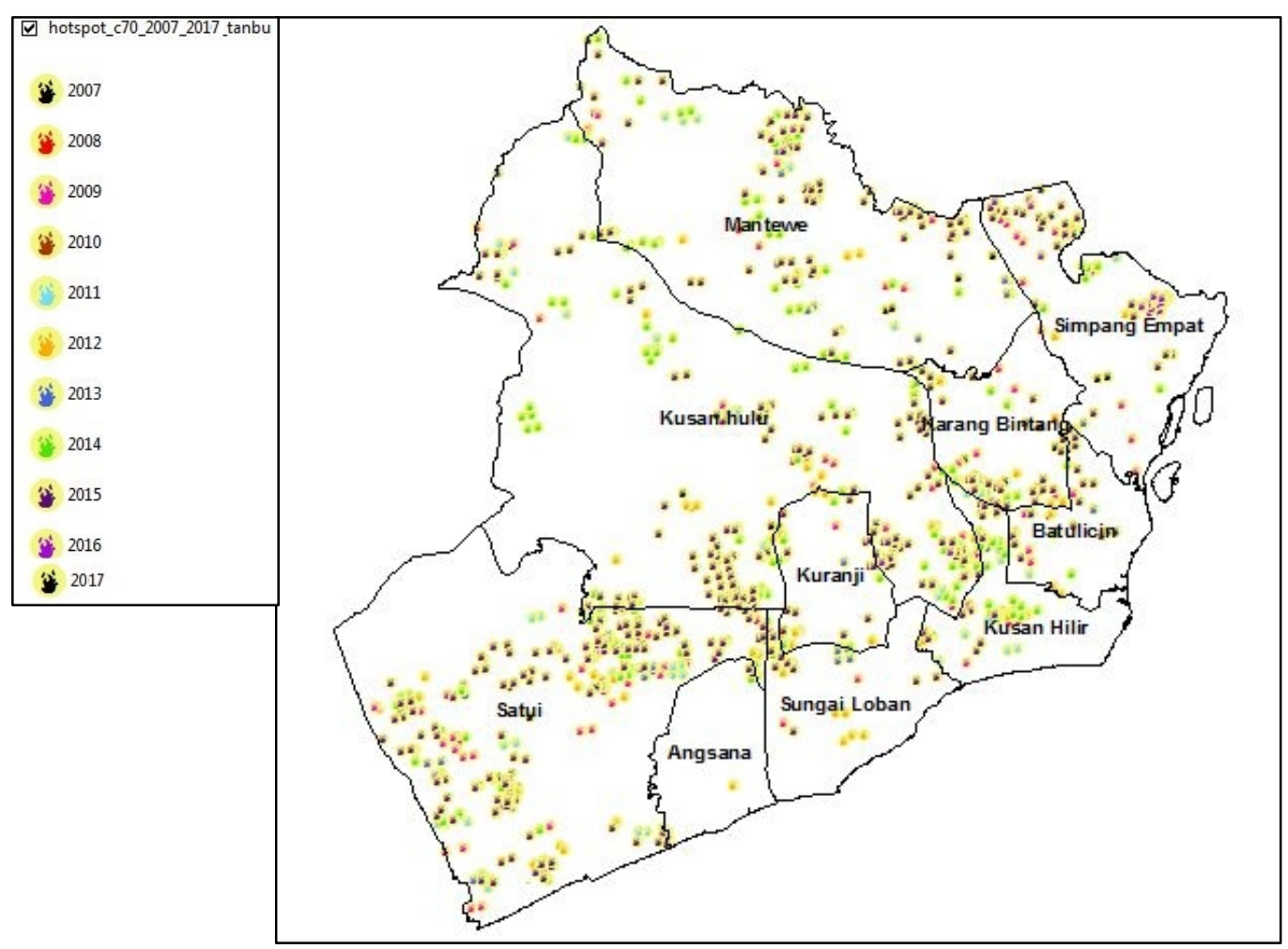

Gambar 2. Sebaran Titik Panas (Hotspot) Kabupaten Tanah Bumbu

\subsection{Resiko Kebakaran Hutan dan Lahan}

Resiko kebakaran hutan dan lahan menggambarkan kemungkinan (probabilitas) terjadinya kebakaran. Tingkatan resiko kebakaran terdiri dari Aman, Tidak Bahaya, Agak Bahaya, Bahaya dan Sangat Bahaya. Semakin tinggi tingkatan resiko kebakaran berarti semakin tinggi juga kemungkinan terjadinya kebakaran pada daerah yang bersangkutan. Sebaran Resiko kebakaran merupakan dugaan potensi riil terjadinya kebakaran hutan dan lahan. Sebaran resiko kebakaran di Kabupaten Tanah Bumbu disajikan pada Gambar 3. 


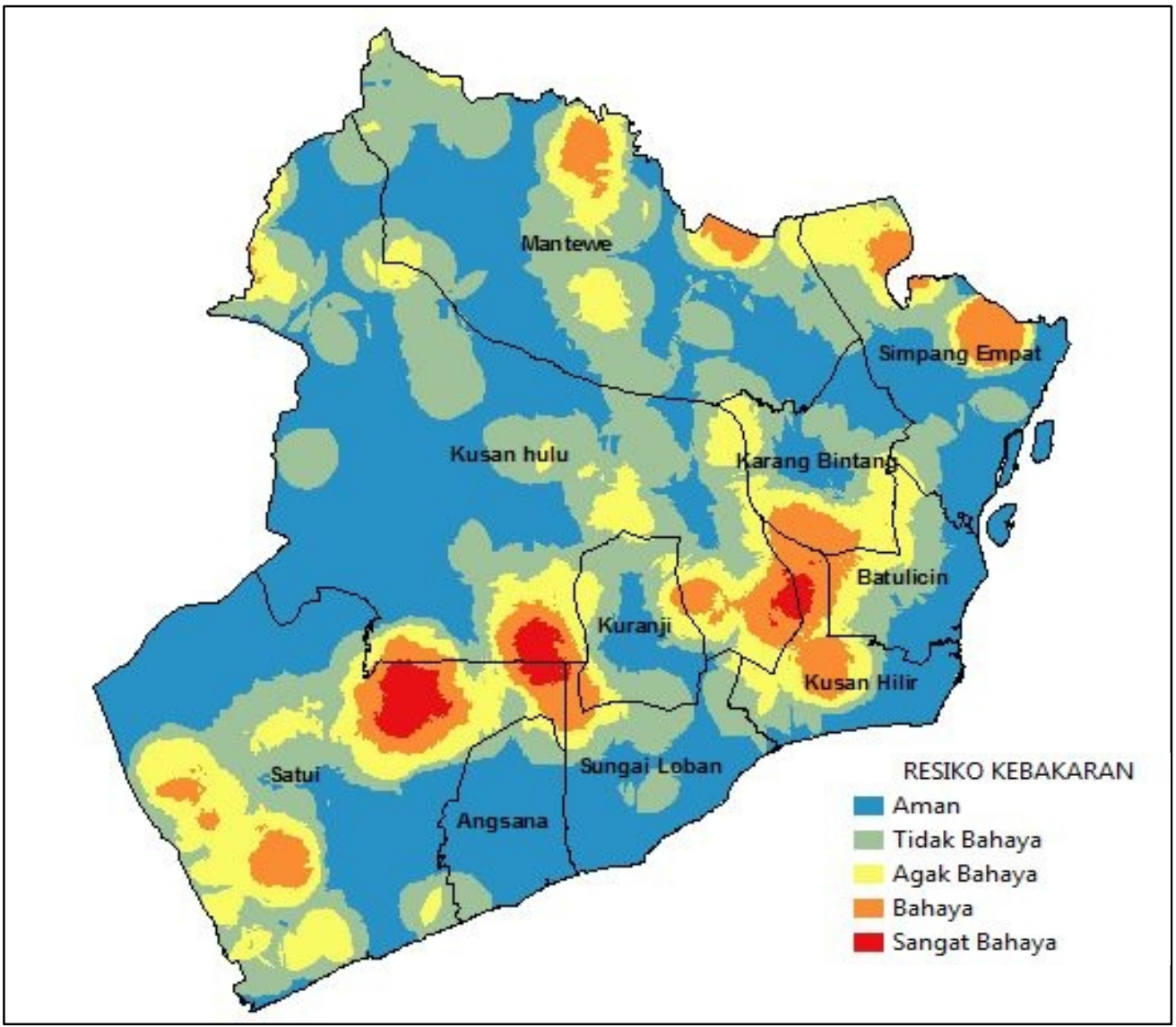

Gambar 3. Resiko Kebakaran Hutan dan Lahan Kabupaten Tanah Bumbu

Daerah dengan resiko kebakaran hutan dan lahan tersebar hampir disemua kecamatan. Sedangkan daerah yang relatif aman adalah daerah yang kurang diintervensi manusia yakni di sepanjang lereng pegunungan Meratus di bagian utara kecamatan Satui. Kecamatan Kusan Hulu adalah kecamatan yang memiliki luas daerah Aman kebakaran hutan dan lahan paling luas dengan 68.735 ha yang disusul oleh kecamatan Mantewe dengan daerah Aman kebakaran seluas 38.523 ha.

Sedangkan kecamatan yang memiliki resiko kebakaran hutan dan lahan Sangat Bahaya paling luas adalah Kecamatan Satui dan Kusan Hulu dengan luas masing-masing 4.524 ha dan 2.291 ha. Dengan resiko di bawahnya, yaitu resiko Bahaya, didominasi kecamatan Satui dan kecamatan Kusan Hulu dengan masing-masing 9.671 ha dan 7.387 ha. Selanjutnya pada resiko Agak Bahaya dominasi ada pada kecamatan Satui seluas 26.342 ha dan Kusan Hulu seluas 19.165 ha. Pada kelas dibawahnya yakni resiko Tidak Bahaya dominan pada kecamatan Kusan Hulu seluas 49.497 ha disusul oleh kecamatan Mentewe 41.340 ha. 
Tabel 4. Luas Resiko Kebakaran Hutan dan Lahan Kabupaten Tanah Bumbu

\begin{tabular}{|c|c|c|c|c|c|c|}
\hline \multirow[b]{2}{*}{ Nama Kecamatan } & \multicolumn{5}{|c|}{ RESIKO KEBAKARAN } & \multirow[b]{2}{*}{ Total } \\
\hline & Aman & Tidak Bahaya & Agak Bahaya & Bahaya & Sangat Bahaya & \\
\hline Angsana & $14,439.02$ & $3,512.77$ & 367.33 & 3.28 & - & $18,322.41$ \\
\hline Batulicin & $6,072.81$ & $5,515.05$ & $4,163.61$ & 910.09 & - & $16,661.56$ \\
\hline Karang Bintang & $6,981.39$ & $6,721.05$ & $5,925.08$ & $2,740.51$ & - & $22,368.03$ \\
\hline Kuranji & $4,882.03$ & $8,213.37$ & $3,196.75$ & 830.93 & - & $17,123.08$ \\
\hline Kusan Hilir & $6,660.21$ & $3,562.22$ & $4,025.81$ & $5,270.52$ & 649.97 & $20,168.73$ \\
\hline Kusan hulu & $68,735.22$ & $49,496.84$ & $19,164.76$ & $7,386.69$ & $2,291.42$ & $147,074.92$ \\
\hline Mantewe & $38,525.78$ & $41,339.89$ & $10,871.36$ & $3,770.76$ & - & $94,507.79$ \\
\hline Satui & $38,480.19$ & $26,710.16$ & $26,341.58$ & $9,670.72$ & $4,524.00$ & $105,726.64$ \\
\hline Simpang Empat & $16,984.67$ & $10,177.34$ & $6,980.95$ & $4,862.86$ & - & $39,005.83$ \\
\hline Sungai Loban & $15,472.64$ & $7,763.11$ & $1,343.52$ & $1,087.71$ & 70.04 & $25,737.02$ \\
\hline Total & $217,233.97$ & $163,011.79$ & $82,380.76$ & $36,534.05$ & $7,535.43$ & $506,696.00$ \\
\hline
\end{tabular}

\subsection{Kerawanan Kebakaran Hutan dan Lahan}

Jika dilihat dari pola terjadinya kebakaran hutan dan lahan, terlihat adanya hubungan antara faktor tutupan lahan, aksesibilitas dan aktifitas manusia baik yang sifatnya perorangan maupun korporasi. Pada dasarnya dari pola sebaran titik api tersebut dapat dilihat bahwa pola terjadinya kebakaran adalah gabungan dari faktor tersedianya sumber bahan bakar, rendahnya kelembaban akibat kurangnya kanopi penutup, musim panas dan faktor kesengajaan dengan motivasi ekonomi. Sebaran titik api berdasarkan tutupan lahan dapat dilihat pada Tabel 5.

Tabel 5. Sebaran Titik Panas (Hotspot) Berdasarkan Tutupan Lahan di Kabupaten Tanah Bumbu

\begin{tabular}{|c|c|c|c|c|c|c|c|c|c|c|c|c|c|c|c|c|}
\hline \multirow{2}{*}{$\begin{array}{c}\text { Nama } \\
\text { Kecamatan }\end{array}$} & A & $\mathbf{B}$ & $\mathbf{B r}$ & Hms & Hrs & Hs & Ht & Pb & Pc & Pk & Pm & Pt & Rw & Sw & T & Hotspot \\
\hline Angsana & & & 2 & & & & 1 & & & 2 & & 1 & & & & 6 \\
\hline Batulicin & & & 1 & & & & & & 2 & 22 & & & 4 & 2 & & 31 \\
\hline Karang Bintang & & & 11 & & 1 & & & & & 27 & & 17 & 1 & & & 57 \\
\hline Kuranji & & 1 & & & & & 4 & & 9 & 6 & & 12 & & & & 32 \\
\hline Kusan Hilir & & & 8 & & 1 & & 4 & & 1 & & & 26 & 11 & 15 & & 66 \\
\hline Kusan hulu & & 46 & 11 & & 2 & 43 & 30 & 5 & 16 & 12 & & 47 & 1 & 18 & 4 & 235 \\
\hline Mantewe & & 30 & & & & 94 & & 4 & & 5 & & 20 & & & & 153 \\
\hline Satui & & 115 & 6 & 1 & & 6 & 41 & 18 & 16 & 18 & & 29 & & & 11 & 261 \\
\hline Simpang Empat & & 37 & 1 & & & 2 & & 1 & 12 & 24 & & 7 & & & & 84 \\
\hline Sungai Loban & & 2 & & & & & 11 & & 4 & & & 10 & & & 1 & 28 \\
\hline Total & $\mathbf{0}$ & $\mathbf{2 3 1}$ & $\mathbf{4 0}$ & $\mathbf{1}$ & $\mathbf{4}$ & $\mathbf{1 4 5}$ & $\mathbf{9 1}$ & $\mathbf{2 8}$ & $\mathbf{6 0}$ & $\mathbf{1 1 6}$ & $\mathbf{0}$ & $\mathbf{1 6 9}$ & $\mathbf{1 7}$ & $\mathbf{3 5}$ & $\mathbf{1 6}$ & $\mathbf{9 5 3}$ \\
\hline
\end{tabular}




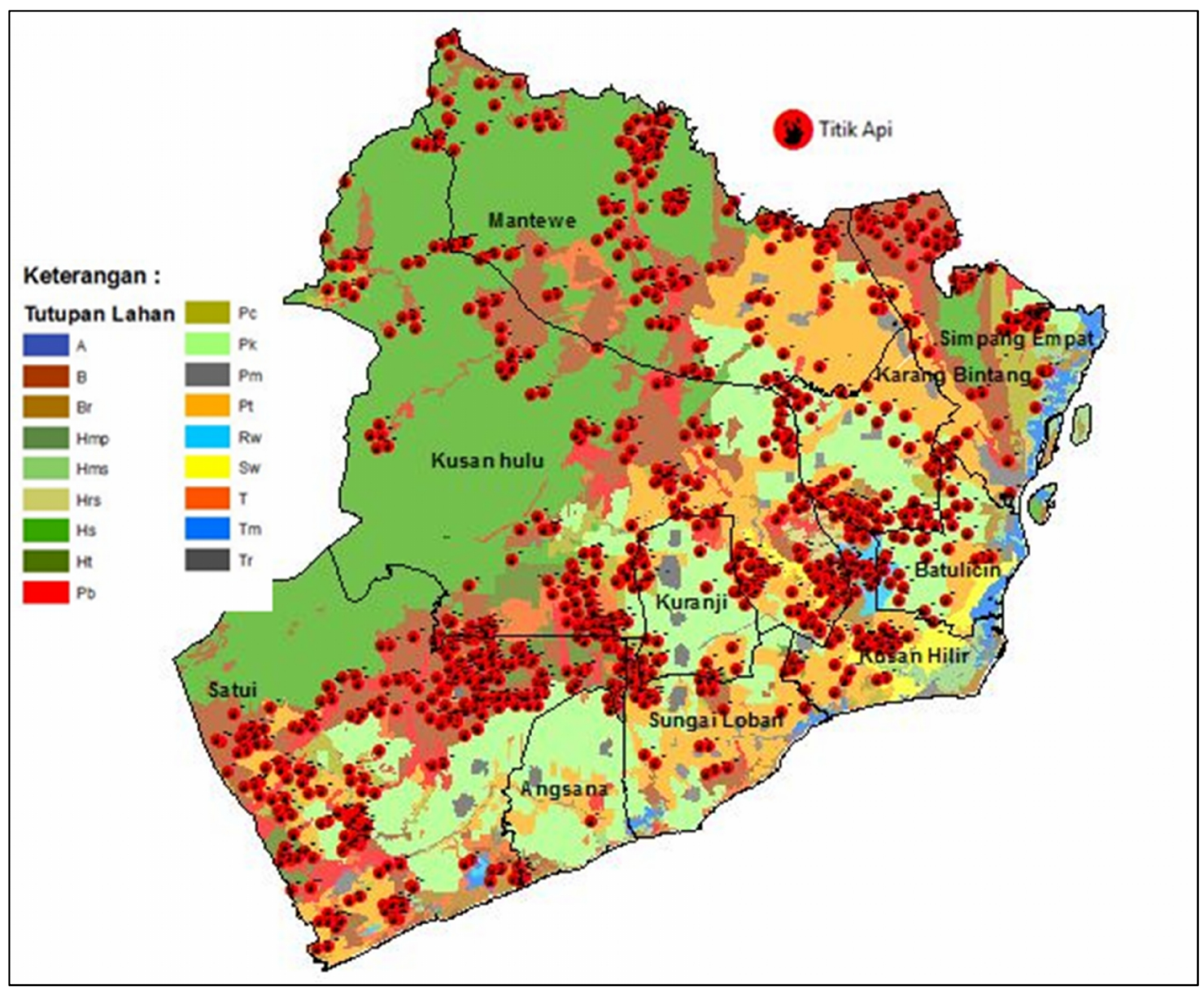

Gambar 4. Overlay Sebaran Titik Panas (Hotspot) dengan Tutupan Lahan Kabupaten Tanah Bumbu

Dari sisi tutupan lahan, sebagaimana bisa dilihat pada gambar 4.7 dapat dilihat bahwa tutupan lahan yang paling sering ada titik apinya selama 10 tahun terakhir adalah tutupan lahan Belukar (B) dengan total titik api sebanyak 231. Data ini menginformasikan bahwa kebakaran pada area ini umumnya adalah kebakaran yang disengaja untuk pembukaan dan pembersihan lahan perorangan, mengingat polanya yang selalu berdekatan dengan tutupan lahan Pertanian lahan kering $(\mathrm{Pt})$. Tutupan lahan terbanyak kedua penyumbang titik api adalah Pertanian lahan kering $(\mathrm{Pt})$ dengan titik api sebanyak 169 buah. Hal ini semakin menguatkan dugaan bahwa terjadinya api adalah faktor kesengajaan.

Pada urutan ketiga tutupan lahan dengan titik api terbanyak adalah Hutan sekunder (Hs) sebanyak 145 buah. Data ini menginformasikan bahwa di area ini ada kegiatan manusia dengan motif ekonomi baik perorangan maupun korporasi. Artinya telah terjadi pembukaan lahan secara spot-spot yang membuat iklim mikro hutan terganggu dan 
kelembaban hutan menjadi rendah. Pada posisi normal, Hutan sekunder memiliki kelembaban yang cukup tinggi, sehingga akan sulit terjadi kebakaran secara alami.

Pada urutan ke empat, tutupan lahan penyumbang titik api adalah Perkebunan (Pk) sebanyak 116 buah. Tutupan ini umumnya didominasi oleh perkebunan Sawit. Api pada area tutupan ini idealnya memang tidak terjadi karena ada manajemen yang bertanggung jawab pada wilayahnya. Sehingga jika ada kejadian pada wilayahnya maka pihak manajemen bisa dimintai pertanggung jawabanya.

Hal yang sama juga berlaku pada area dengan tutupan lahan Hutan tanaman (Ht), karena ada manajemen yang bertanggung jawab pada wilayah tersebut. Tercatat selama 10 tahun terakhir ada 91 kejadian di area ini. Dengan demikian (Ht) adalah penyumbang ke lima bagi timbulnya titik api.

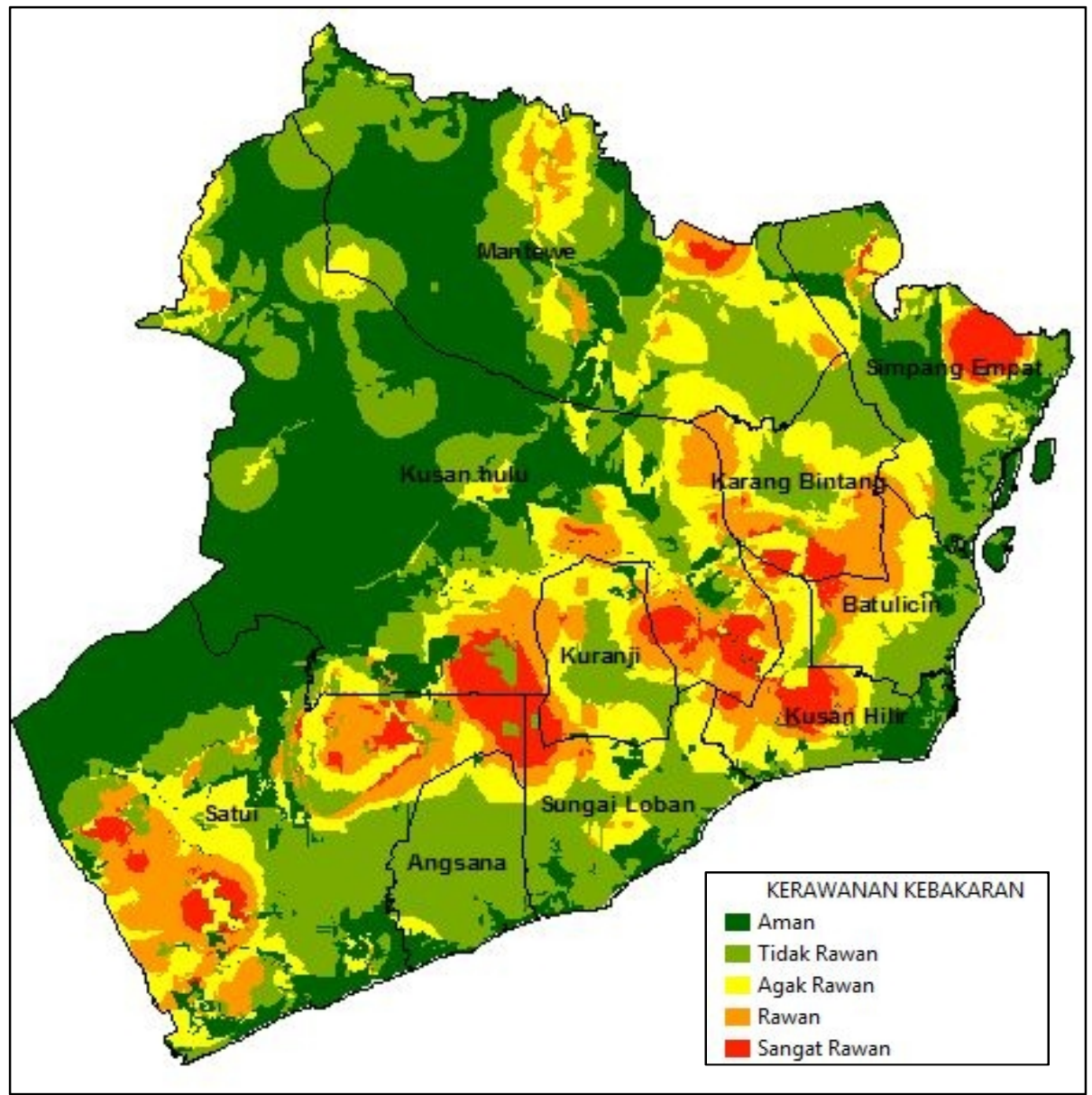

Gambar 5. Kerawanan Kebakaran Hutan dan Lahan Kabupaten Tanah Bumbu 
Kerawanan kebakaran hutan dan lahan menggambarkan perpaduan antara resiko (probabilitas) terjadinya kebakaran dengan penggunaan lahan, aksesibilitas, permukiman dan bangunan penting, iklim, topografi, serta sejarah kejadian kebakaran hutan dan lahan. Tingkatan kerawanan terdiri dari aman, tidak rawan, agak rawan, rawan dan sangat rawan. Semakin tinggi tingkat kerawanan berarti semakin tinggi pula resiko kebakaran pada satu peruntukan lahan tertentu. Sebaran kerawanan kebakaran di Kabupaten Tanah Bumbu disajikan pada Gambar 5.

Mayoritas daerah dengan kerawanan kebakaran hutan dan lahan (skor selain Aman) berada di bagian sebelah tengah ke selatan, memanjang dari kecamatan Satui ke kecamatan Simpang Empat. Kecamatan Kusan Hulu adalah kecamatan yang memiliki luas daerah Aman dari kerawanan kebakaran paling luas dengan 74.538 ha yang disusul oleh kecamatan Satui dengan daerah Aman seluas 34.744 ha dan kecamatan Mantewe seluas 34.672 ha.

Adapun kecamatan yang memiliki kerawanan kebakaran Sangat Rawan paling luas adalah Kecamatan Satui dengan luas 6.607 ha dan kecamatan Kusan Hulu seluas 6.245 ha. Pada tingkatan resiko yang lebih rendah yaitu tingkatan Rawan, kembali kecamatan Satui dan Kusan Hulu menduduki urutan atas dengan luas masing-masing 20.117 ha, dan 12.723 ha.

Tabel 6. Luas Kerawanan Kebakaran Hutan dan Lahan Kabupaten Tanah Bumbu

\begin{tabular}{|c|c|c|c|c|c|c|}
\hline \multirow[b]{2}{*}{ Nama Kecamatan } & \multicolumn{5}{|c|}{ KERAWANAN } & \multirow[b]{2}{*}{ Total } \\
\hline & Aman & Tidak Rawan & Agak Rawan & Rawan & Sangat Rawan & \\
\hline Angsana & $1,667.21$ & $13,681.58$ & $2,577.75$ & 340.55 & 3.15 & $18,270.24$ \\
\hline Batulicin & $1,328.42$ & $5,446.25$ & $5,783.74$ & $3,560.37$ & 496.59 & $16,615.36$ \\
\hline Karang Bintang & - & $7,227.03$ & $7,446.73$ & $6,083.00$ & $1,654.39$ & $22,411.16$ \\
\hline Kuranji & 418.42 & $4,899.92$ & $6,867.22$ & $4,098.58$ & 871.96 & $17,156.10$ \\
\hline Kusan Hilir & $3,576.93$ & $3,738.95$ & $5,824.56$ & $4,315.32$ & $2,578.77$ & $20,034.53$ \\
\hline Kusan hulu & $74,537.78$ & $34,790.27$ & $19,051.53$ & $12,723.47$ & $6,246.90$ & $147,349.96$ \\
\hline Mantewe & $34,671.80$ & $36,079.88$ & $18,322.96$ & 4,957.46 & 656.03 & $94,688.13$ \\
\hline Satui & $34,743.50$ & $26,154.85$ & $18,085.56$ & $20,116.84$ & $6,606.81$ & $105,707.57$ \\
\hline Simpang Empat & $12,024.91$ & $14,644.41$ & $7,040.87$ & $1,924.57$ & $3,231.57$ & $38,866.33$ \\
\hline Sungai Loban & $3,601.28$ & $12,814.72$ & $6,296.40$ & $1,742.73$ & $1,141.50$ & $25,596.63$ \\
\hline Total & $166,570.25$ & $159,477.86$ & $97,297.33$ & $59,862.88$ & $23,487.68$ & $506,696.00$ \\
\hline
\end{tabular}

Berdasarkan hasil tersebut di atas dapat dilihat bahwa resiko kebakaran hutan dan lahan berkorelasi positive dengan aksesibilitas dan jumlah serta tingkat kegiatan oleh penduduk. Semakin tinggi jumlah dan tingkat kegiatan penduduk disekitar ditambah dengan kemudahan aksesibiltas maka semakin tinggi juga resiko kebakaran hutan dan lahan. 
Jurnal Planologi Vol. 17 No. 2, Oktober 2020

Available : http://jurnal.unissula.ac.id/index.php/psa

Dari pola sebaran hotspot dan kejadian kebakaran dapat disimpulkan bahwa rendahnya kerapatan dan tingkat kegiatan manusia adalah faktor utama rendahnya tingkat kerawanan kebakaran hutan dan lahan. Sebaliknya, semakin terbuka aksesibilitas dan semakin banyak kegiatan manusia ini juga lah yang menyebabkan tingginya tingkat kerawanan kebakaran hutan dan lahan di kecamatan-kecamatan yang ada di kabupaten Tanah Bumbu.

Faktor manusia berpengaruh terhadap intensitas tingkat pembukaan lahan yang berkorelasi positif terhadap perubahan tutupan lahan. Tutupan lahan inilah yang bersama faktor panas dan kekeringan akan menjadi bahan bakar terjadinya kebakaran. Semakin berubah tipe tutupan lahan dari hutan ke belukar atau ilalang maka semakin tinggi resiko terjadinya kebakaran.

Pada kasus pola terjadinya kebakaran di kabupaten Tanah Bumbu, sebagian besar kebakaran hutan dan lahan berasal dari kegiatan pembakaran pada sistem pengolahan lahan di pedesaan maupun wilayah yang dikuasai korporasi.

Pembakaran juga dilakukan pada lahan pertanian seperti sawah dan ladang menetap untuk menghilangkan sisa-sisa panenan, serta pada lahan calon perkebunan dalam kegiatan persiapan lahan tanam. Karena kebakaran biasanya dilakukan pada musim kemarau dan tidak atau kurang diawasi, maka api dengan mudah merambat ke kawasan hutan dan lahan di sekitarnya dan menyebabkan kebakaran hutan dan lahan yang merugikan secara ekonomis dan ekologis.

Dalam skala yang sporadis pada areal Hutan sekunder di pegunungan Meratus, pembukaan kawasan hutan untuk membuka suatu areal baru bagi tanaman pangan sudah lama berlangsung. Biasanya setelah 2 atau 3 tahun ditanami tanaman pangan, lahan tersebut menjadi miskin hara dan ditinggalkan. Selanjutnya pembukaan kawasan hutan yang lainnya terjadi lagi untuk maksud yang sama. Demikian terus-menerus, bahkan meningkat sejalan dengan meningkatnya jumlah penduduk.

\section{KESIMPULAN DAN SARAN}

\subsection{Kesimpulan}

Berdasarkan penelitian dan pembahasan yang telah dilakukan, dapat disimpulkan beberapa hal sebagai berikut:

1. Zonasi tingkat kerawanan kebakaran hutan dan lahan di Kabupaten Tanah Bumbu terdiri dari lima kelas yaitu daerah aman seluas 166.570, 21 hektar (32,87\%), daerah 
tidak rawan seluas 159.477,86 hektar (31,47\%), daerah agak rawan seluas 97.297,33 hektar $(19,2 \%)$, daerah rawan seluas 59.862,88 hektar $(11,81 \%)$, dan daerah sangat rawan seluas 23.487,68 hektar (4,63\%).

2. Tutupan lahan yang paling sering terjadi kebakaran hutan dan lahan adalah belukar, pertanian lahan kering, hutan sekunder, perkebunan, dan hutan tanaman.

3. Kecamatan yang memiliki tingkat kerawanan kebakaran hutan yang tinggi adalah Kecamatan Satui dan Kecamatan Kusan Hulu. Sedangkan kecamatan yang memiliki tingkat kerawanan terendah adalah Kecamatan Angsana, Batulicin, dan Kecamatan Mantewe.

4. Faktor utama terjadinya kebakaran hutan dan lahan di kabupaten Tanah Bumbu lebih disebabkan karena faktor iklim berupa musim kemarau dan pemansan global. Faktor lainnya adalah faktor kelalaian manusia berupa pembakaran lahan untuk mengeksploitasi sumberdaya alam dan lahan garapannya.

\subsection{Saran}

Dengan adanya informasi spasial berupa peta kerawanan kebakaran hutan di Kabupaten Tanah Bumbu, diharapkan dapat meningkatkan kinerja pemerintah daerah dalam upaya penanggulangan bencana kebakaran hutan mulai dari tahap pencegahan, tanggap darurat, hingga pemulihan pasca kebakaran hutan. Pemerintah Daerah juga dapat menggunakan peta ini sebagai dasar untuk penentuan daerah yang diprioritaskan untuk segera ditangani serta untuk perencanaan penggunaan lahan yang komprehensip dan menggabungkannya dengan pembangunan berkelanjutan. selain itu sebagai input dalam kegiatan kontingensi khususnya kebakaran lahan dan hutan sebagai dasar dalam penentuan kebiajakan startegi dan program kegiatan pada kondisi kesiapsiagaan. Sedangkan bagi swasta dan masyarakat, dapat dijadikan pertimbangan dalam penentuan lokasi lokasi yang layak dalam rangka melakukan investasi khusunya dalam bidang kehutanan.

\section{DAFTAR PUSTAKA}

Amalina, Putri. (2015). Pemetaan Kerawanan Kebakaran Hutan di Taman Nasional Way Kambas. Skripsi. Departemen Konservasi Sumberdaya Hutan dan Ekowisata Fakultas Kehutanan Institut Pertanian Bogor.

ESRI. (2009). Spatial Reference Properties WGS_1984_UTM_Zone_50N. ESRI. Redlands. 
Farandika, A., \& Hartono, H. (2016). Aplikasi Penginderaan Jauh dan Sistem Informasi Geografi untuk Pemetaan Kerawanan Kebakaran Hutan dan Lahan di Kawasan Cagar Biosfer Giam Siak Kecil-Bukit Batu Provinsi Riau. Jurnal Bumi Indonesia, 5(2), 228660.

Kusmajaya, S., Supriyati, S., Adiputra, A., \& Permadi, M. G. (2019). Pemetaan Bahaya dan Kerentanan Bencana Kebakaran Hutan dan Lahan di Provinsi Riau. Jurnal Geografi, Edukasi dan Lingkungan (JGEL), 3(1), 55-61.

Moehansyah (2015). Kerawanan Bencana Banjir, Kekeringan dan Kebakaran di Kalimantan Selatan Ditinjau dari Biofisik dan Konservasi Lahannya. Pusat Penelitian Pengembangan Wilayah Lembaga Penelitian Universitas Lambung Mangkurat. Banjarmasin.

Nursoleha, P., Banowati, E., \& Parman, S. (2014). Zonasi Tingkat Kerawanan Kebakaran Hutan Di Taman Nasional Gunung Ciremai (Tngc) Berbasis Sistem Informasi Geografis (SIG). Geo-Image, 3(1). 1-6.

Pualilin, Y., Tjoneng, A., \& Abdullah, A. (2019). Pemetaan Zonasi Daerah Rawan Kebakaran Hutan Dan Lahan Di Kabupaten Gowa. AGROTEK: Jurnal Ilmiah Ilmu Pertanian, 3(1), 89-97.

Sakarov, O. D. (2019). Analisis Kesesuaian Lahan Untuk Lokasi Permukiman di Kabupaten Belu Nusa Tenggara Timur. Jurnal Planologi, 16(1), 16-31.

Samsuri, I. N. S., \& Syaufina, L. (2008). Model Spasial Tingkat Kerawanan Kebakaran Hutan dan Lahan (Studi Kasus di Wilayah Propinsi Kalimantan Tengah). Foresta Indonesian Journal of Forestry, 1(1), 12-18.

SE Bupati Tanah Bumbu, No 360/ BPBD/ VIII/ 2015 tentang Larangan Membakar Hutan Dan Lahan

Rahman, B., Fimanasari, R., \& Sari, U. C. (2019, October). The Analysis of Landslide Vulnerability in Settlement of Citizenship Association VI, Sukorejo Village, Semarang. In IOP Conference Series: Earth and Environmental Science (Vol. 328, No. 1, p. 012035). IOP Publishing.

Rencana Tata Ruang Wilayah Kabupaten Tanah Bumbu tahun 2017 - 2037

Undang Undang 41 Tahun 1999 Tentang Kehutanan

Undang Undang 32 Tahun 2009 Tentang Perlindungan dan Pengelolaan Lingkungan Hidup 